Japanese Journal of Transfusion Medicine, Vol. 35. No. 6 35(6): 653-658, 1989

技術

$$
\begin{gathered}
\text { 白血球除去赤血球の製造のための小型フィルターを } \\
\text { 組み込んだ } 5 \text { 連バックシステム }
\end{gathered}
$$$$
\text { 宮原 正行 大熊 重則 西崎太計志 }
$$

岡山県赤十字血液センター

(平成元年 7 月 20 日受付)

\title{
QUINTUPLE-BAG SYSTEM WITH A SMALL FILTER FOR PREPARING LEUKOCYTE-DEPLETED RED BLOOD CELLS
}

\author{
Masayuki Miyahara, Shigenori Ohkuma and Takeshi Nishizaki \\ Okayama Red Cross Blood Center
}

A quintuple-bag system with a small filter was devised to prepare leukocyte-depleted red blood cells in a closed system. This system is a combination of buffy coat removal by centrifugation and filtration through cotton filter. Approximately $65 \%$ of leukocytes were removed in the first step, centrifugation process, and approximately $98 \%$ of leukocytes were removed in the following filtration process. Removal of leukocytes increased up to $99 \%$ when the filtration was carried out at $4-6^{\circ} \mathrm{C}$. Thus, the number of leukocytes remaining in the red cell concentrates derived from $400 \mathrm{ml}$ of blood was estimated to be approximately $1.4 \times 10^{7} /$ unit. Therefore, if the red cells prepared by this method are used, the risk of HLA immunization can probably be prevented.

\section{はじめに}

近年の成分輸血の発達は, 輸血療法に著しい進 歩をもたらしたが，反面血液の使用量を飛躍的に 増大させ，それに伴ら輸血副作用が新たな問題と して提起されてきた。特に，血液製剂中に含まれ ている白血球が輸血副作用の原因となることが多 く, 発熱, 悪寒など1) 3)のような以前から指摘され ていた副作用だけでなく, 最近は抗白血球 (HLA) 抗体の産生や ${ }^{4) 5}$ graft versus host $(\mathrm{GVH})$ 反応 ${ }^{6) \sim 8)}$ などによる副作用が大きな問題となってきてい る。そのため, 今後の輸血に打いては, 白血球を できるだけ除去した血液製剤を用いることが望ま しいと思われる。

従来から，乏白血球製剤として洗浄赤血球や白 血球除去赤血球が日本赤十字社血液センターから 供給されているが，いずれも open system で製造 されるので有効期限が製造後 24 時間と短く, 限ら れた患者だけに少量製造されているに過ぎない。
また，その白血球除去率が HLA 抗体産生や GVH 反応の防止のためには必ずしも十分でない ことなど，改良すべき点も多い。

このような観点から, 我々は以前に 4 連バック を用いた non-button PC 法を考案し, 濃厚赤血球 や濃厚血小板から closed system で白血球が除去 できることの他，機能の良好な血小板が得られる こと，血浆の収量が現行法より $20 \sim 30 \%$ 高くなる こと, 赤血球の保存期限が約 2 週間延長できるこ となど,多くの利点が得られることを示した ${ }^{910)}$. 現在，この方法の実用化を目指し，機械を用いて 自動化することが検討されている(11)17). しかし，こ の方法だけでは, 濃厚赤血球に拈ける白血球除去 率が約65\%であり，最近問題になっている HLA 抗体や GVH 反応の防止の目的には不十分である と思われる，そこで，当研究では，濃厚赤血球の 白血球除去率をさらに向上させるため，このシス テムに小型の白血球除去フィルターを組み込んだ 
5 連バックシステムを考案した。

当システムを考案する際，上記で指摘した問題 点を解決するため, 特に次の 3 点について考慮し た。（1）白血球除去率の目標は，少なくとも現行 の白血球除去赤血球の白血球除去率（90～95\%） 以上とする. (2) 白血球を効率的に除去するため, 原理の異なった除去方法である遠心法とフィル ター法を組み合わせる。（3）白血球除去赤血球の 有効期限を現行法より大幅に長くするため, closed system で製造でさるようにする，以上の 観点から, 今回考案した 5 連バックシステムの有 効性について検討した。

\section{方 法}

当研究で考案した 5 連バックシステムを図 1 に 示す。このシステムでは, 親バッグと第 4 子バッ グ (SAGP-maltose 液) ${ }^{9}$ の間に小型の白血球除去 フィルター(テルモ社特注品, カラムの直径 $2 \mathrm{~cm}$, 長さ $10 \mathrm{~cm}$, エジプト綿重量 $5 ７ \mathrm{~g}$ )が組み込まれて いる.

このシステムを用いた血液成分製剤の製造法は 以下の通りである。最初に, $400 \mathrm{~m} l$ の血液を親 バッグ (CPD 液) に採血し，これを $3,500 \times \mathrm{g}$ で 5 ～6 分間遠心する. 上層の血浆を第 1 子バッグに 移行させ, buffy coat 層が親バッグの排出ロから
約 $3.5 \mathrm{~cm}$ のところ（白線の目印）に達した時止め る. 次に, 親バッグ中の残存血浆と血小板を含む buffy-coat 層を合わせて約 $70 \mathrm{~m} l$ を第 2 子バッグ （ミニバッグ）に移す、a 点及び b 点をシールした 後切り離し, 第 1 子バッグをー $20^{\circ} \mathrm{C}$ 以下で涷結し て新鮮凍結血浆とする. 第 2 子バッグと第 3 子 バッグを連結したまま $1,800 \times \mathrm{g}$ で 5 〜 6 分間遠 心し，上層の血奨 (血小板が浮遊) 約 $40 \mathrm{~m} l$ を第 3 子バッグへ移し, 濃厚血小板 $(\mathrm{PC})$ を得る。次に, 第 4 子バッグの SAGP-maltose 液をフィルター に通してプライミングし, 同時にその液で赤血球 を浮遊させる。赤血球を均一に再浮遊させた後, 親バッグ（上）と第 4 子バッグ（下）の落差が約 $60 \mathrm{~cm}$ になるように吊るし, 赤血球浮遊液をフィ ルターで滤過して白血球除去赤血球を得る。低温 で濾過する時は, $4 \sim 6{ }^{\circ} \mathrm{C}$ の冷蔵室で同様な操作 を行った。

濃厚赤血球中の残存白血球数は, Vakkila 等の 方法にしたがって計数した ${ }^{12)}$.すなわち，10〜15 $\mathrm{m} l$ の赤血球に対し 10 倍量の $0.83 \% \mathrm{NH}_{4} \mathrm{Cl}, 0.01$ $\mathrm{M} \mathrm{KHCO}_{3}$ (pH 7.4) を加え, 赤血球を溶血させ る. 次に, PBS, RPMl-1640 (5\%FCS) でそれ ぞれ洗浄後, 後者の液に再浮遊させ, チュルク染 色液で染色し，視算法（検鏡）により白血球を計

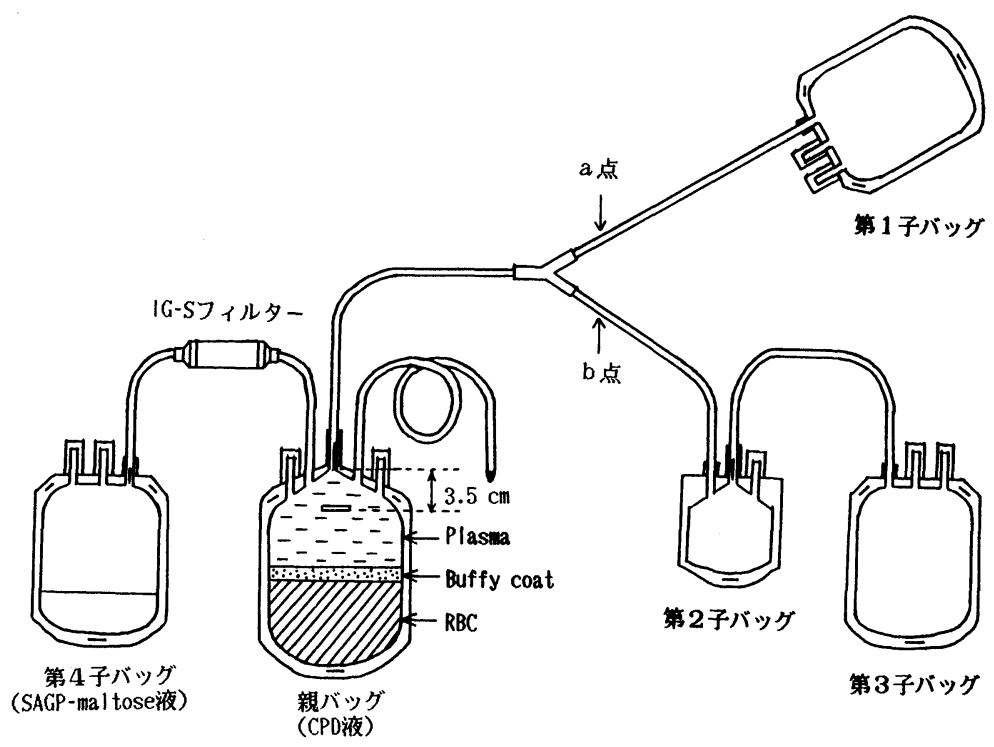

図 1 小型白血球除去フィルター（IG-S）を組み込んだ 5 連バッグシステム 
数した. 残存白血球の分類はペルオキシダーゼ染 色 (PO-K 染色キット, 武藤化学)を用いて行った. な报，赤血球の計数には，Sysmex E-5000を用い た.

\section{結 果}

フィルターを含まない 5 連バッグシステムに よって製造した濃厚赤血球の白血球除去率を表 1 に示す。このデータから, 遠心法 (non-button PC 法）によって，リンパ球は約 $90 \%$ 除去できたが, な和顆粒球が約 $50 \%$ 残存することが示された。

各種の小型フィルターを組み込んだ 5 連バッグ システムによって製造した濃厚赤血球の白血球除

表 1 Non-button PC 法(遠心工程)で 製造した $400 \mathrm{~m} l$ 由来濃厚赤血球の白 血球除去率

\begin{tabular}{c|c|c}
\hline & $\begin{array}{c}\text { 白血球残存量 } \\
\left(\times 10^{8} / \text { unit }\right)\end{array}$ & $\begin{array}{c}\text { 白血球除去率 } \\
(\%)\end{array}$ \\
\hline 総白血球 & $8.46 \pm 2.94$ & $66.5 \pm 3.2$ \\
リンパ球 & $0.61 \pm 0.32$ & $92.8 \pm 3.2$ \\
顆粒球 & $7.24 \pm 2.82$ & $53.3 \pm 16.3$ \\
\hline
\end{tabular}

$\mathrm{n}=18$
去率を表 2 に示す。この実験では，原料血液の個 体差による実験誤差を少なくするため，nonbutton PC 法で製造した濃厚赤血球の数単位をあ らかじめプールし，これを室温で各種のフィル ターに通した。 Polyester (PET) 系フィルターは 白血球アフェレーシスのロイカラム（テルモ社） と同じ材料が使用されているので, 白血球に対し て強い吸着力を持つと予想されたが，実際はイム ガード（IG）フィルターより白血球除去効果が低 かった。種々の綿重量の IG フィルターを比較す ると, 綿重量の増加に応じて濾過時間が長くなっ たが，白血球除去率は上昇する傾向を示した。白 血球除去率の当初の目標は 90 ～95\%以上としたの で, 綿重量は少なくとも $6 \mathrm{~g}$ 以上必要であると考兄 られる。

次に，イムガードフィルターの綿重量 $6 \mathrm{~g}$ と $7 \mathrm{~g}$ のものについて,さらに濾過温度等の条件を変え, 白血球除去効率の改善を試みた。その結果, 濾過 温度を室温から $4 \sim 6{ }^{\circ} \mathrm{C}$ 変更すると, 白血球の 除去率がさらに上昇し, 残存する白血球数は同条 件の室温における濾過法に比べて $1 / 2 \sim 1 / 3$ に低下

表 2 小型白血球除去フィルター付き 5 連バッグシステムで製造した濃厚赤血球の性状*

\begin{tabular}{|c|c|c|c|c|c|c|}
\hline \multirow[b]{2}{*}{ フィルター } & \multirow{2}{*}{$\begin{array}{c}\text { フィルター } \\
\text { 綿重量 } \\
\text { (g) }\end{array}$} & \multirow{2}{*}{$\begin{array}{l}\text { 沪過 } \\
\text { 落差 } \\
(\mathrm{cm})\end{array}$} & \multirow{2}{*}{$\begin{array}{l}\text { 洰過 } \\
\text { 時間 } \\
(\mathrm{min})\end{array}$} & \multicolumn{3}{|c|}{ 白 血 球 除 去 率 } \\
\hline & & & & $\begin{array}{c}\text { 遠心工程 } \\
\text { (\%) }\end{array}$ & $\begin{array}{c}\text { 沪過工程 } \\
(\%)\end{array}$ & 全 $\frac{T}{(\%)}$ 程 \\
\hline IG-S5 & 5 & 60 & 34 & 67.1 & 78.0 & 93.5 \\
\hline IG-S6 & 6 & 60 & 70 & 67.1 & 86.9 & 95.6 \\
\hline IG-S7 & 7 & 60 & 127 & 67.1 & 91.3 & 97.3 \\
\hline PET-S5 & 5 & 60 & 22 & 67.1 & 39.2 & 79.4 \\
\hline PET-S5 & 5 & 40 & 32 & 67.1 & 46.5 & 81.9 \\
\hline
\end{tabular}

*この実験では，フィルターの性能を正確に比較するため, Non-button PC 法(遠心工程)で製 造した 5 単位の $400 \mathrm{~m} l$ 由来の濃厚赤血球をプールした後 5 バッグに再分注し, それぞれを各 フィルターで沪過した。

$\mathrm{IG}=$ Imugard filter(エジプト綿)， PET $=$ Polyester 綿フィルター

表 3 白血球除去率に及ぼす小型イムガードフィルターの綿重量と沪過温度の影響

\begin{tabular}{c|c|c|c|c|c|c|c|c}
\hline フィルター & $\begin{array}{c}\text { フィルター } \\
\text { 重量 }\end{array}$ & $\begin{array}{c}\text { 沪過 } \\
\text { 温度 }\end{array}$ & $\begin{array}{c}\text { 残存白血球数 } \\
\left(\times 10^{7}\right)\end{array}$ & $\begin{array}{c}\text { 自血球除去率 } \\
(\%)\end{array}$ & $\begin{array}{c}\text { 残存白血球の } \\
\text { PO 陽性率* } \\
(\%)\end{array}$ & $\begin{array}{c}\text { 残存リン八゚球数 } \\
\left(\times 10^{7}\right)\end{array}$ & $\begin{array}{c}\text { 沪過時間 } \\
(\mathrm{min})\end{array}$ & $\mathrm{n}$ \\
\hline IG-S6 & $6 \mathrm{~g}$ & $\mathrm{RT}$ & $9.54 \pm 4.68$ & $95.5 \pm 2.4$ & $83.0 \pm 7.8$ & $1.57 \pm 1.11$ & 70 & 5 \\
IG-S6 & $6 \mathrm{~g}$ & $5^{\circ} \mathrm{C}$ & $5.05 \pm 3.06$ & $97.0 \pm 2.3$ & $65.5 \pm 9.9$ & $1.67 \pm 1.06$ & 180 & 5 \\
IG-S7 & $7 \mathrm{~g}$ & $\mathrm{RT}$ & $3.96 \pm 1.48$ & $97.8 \pm 1.5$ & $70.4 \pm 10.6$ & $1.21 \pm 0.81$ & 120 & 5 \\
IG-S7 & $7 \mathrm{~g}$ & $5^{\circ} \mathrm{C}$ & $1.41 \pm 0.57$ & $99.1 \pm 0.7$ & $32.6 \pm 15.1$ & $1.03 \pm 0.56$ & 280 & 5 \\
\hline
\end{tabular}

*PO=ペルオキシダーゼ $\mathrm{RT}=$ room temperature(室温) 
表 4 小型 $\mathrm{IG}>$ フルター付き 5 連バッグシステムと現行の IG フィルター法 の比較

\begin{tabular}{l|c|c|c|c|c}
\hline \multicolumn{1}{c|}{ 方 法 } & 汇過温度 & $\begin{array}{c}\text { 残存白血球数 } \\
\left(\times 10^{2}\right)\end{array}$ & $\begin{array}{c}\text { 白血球除去率 } \\
(\%)\end{array}$ & $\begin{array}{c}\text { 保存期限 } \\
(\text { 旦 })\end{array}$ & $\mathrm{n}$ \\
\hline $\mathrm{IG}-400 \mathrm{Y}^{1)}$ & $\mathrm{RT}$ & $17.50 \pm 16.40$ & $93.8 \pm 5.7$ & 1 & 5 \\
$\mathrm{NBPC}+\mathrm{IG} 400 \mathrm{Y}^{2)}$ & $\mathrm{RT}$ & $1.56 \pm 0.91$ & $99.1 \pm 0.2$ & 1 & 5 \\
$\mathrm{NBPC}+\mathrm{IG}-\mathrm{S}^{3)}$ & $5 \pm 1^{\circ} \mathrm{C}$ & $1.41 \pm 0.57$ & $99.1 \pm 0.7$ & $21 \sim 35$ & 5 \\
\hline
\end{tabular}

1) 通常の濃厚赤血球を $400 \mathrm{~m} l$ 血液用 Imugard filter (IG400Y)で沪過(日赤業務標準 法)

2) Non-button PC 法(NBPC)で製造した濃厚赤血球を $400 \mathrm{~m} l$ 用 Imugard filter (IG400Y)で沪過

3) 小型フィルター(IG-S7)付き 5 連バッグシステムを用いた non-button PC 法 (NBPC)

$\mathrm{RT}=$ room temperature(室温)

した（表 3 ）。特に，IG-S7（綿重量7g）を用いた 場合, 残存白血球数が平均 $1.41 \times 10^{7}$ 個 (白血球除 去率：約 $99 \%$ )となり, 当初の目標を大きく上回っ た。すた，除去される白血球の種類を調べると， ペルオキシターゼ陽性のものの減少率が大きいこ とから，低温で濾過することによって顆粒球が一 層除去され易くなる傾向が認められた。ただし， 低温にすると濾過時間が著しく長くなった。

上記の IG-S7 (closed system, $5{ }^{\circ} \mathrm{C}$ 濾過) と, テルモ社のイムガードフィルターIG-400Yを用い た現行の白血球除去赤血球製造法 (open system, 室温濾過)，および non-button PC 法で製造した 濃厚赤血球を原料として IG-400Yを用いた方法 (open system, 室温濾過) の比較を表 4 に示す. IG-S7を用いた $5{ }^{\circ} \mathrm{C}$ 濾過法は，現行の白血球除去 赤血球より白血球除去率が高く, non-button PC 法と IG-400Y の室温濾過法と組み合わせた場合 とほぼ同等の值を示した。

\section{考 察}

血液製剤から白血球をどの程度除去すればょい かと言う問題には種々の議論がある。たと竞ば, 発熱や悪寒などの副作用を防止するためには約 $1 \times 10^{9}$ 個以下にすればょいと言われている が13114)，抗体価によって異なる可能性がある。 た, HLA 抗体の産生度は, 1 回に輸注される白血 球量だけでなく，輸血の頻度や間隔，また受血者 の免疫応答性などによっても大きく異なる ${ }^{15)}$. そ のため，除去すべき白血球の個数を正確に表すこ
とは容易ではないが，これまでの研究例から総合 的に判断すると, $1 \times 10^{7}$ 個以下にすれば発熱, 悪寒 などの副作用だけでなく，HLA 抗体産生の防止 にも大きな効果を示すものと推定される ${ }^{5) 16)}$. 今回 我々が考案した方法では, $400 \mathrm{~m} l$ 由来の濃厚赤血 球から白血球を約 $99 \%$ 除去（残存白血球数：約 $1.4 \times 10^{7}$ 個)でさることが示されたので，HLA 抗 体産生の防止のためにも有効であると考方られ る。これらの関係をまとめると, 図2のようにな る.

白血球の除去効果を評価する際に注意すべきも ら一つの事項は, 白血球数の表示方法と計数方法 である。たと党ば，除去率 $95 \%$ と言えば，ほとん どの白血球が除去されたような印象を受けるが， 個数で表せばな拈 $2 \sim 5 \times 10^{8}$ 個 $(400 \mathrm{~m} l$ 由来濃厚 赤血球）も残存していることを意味する。また， 白血球数が $1 \times 10^{7}$ 個以下になると, 通常の自動血 球計数器による測定法では誤差が大きい。このよ らな低濃度の白血球を計数する場合は, 前処理と して検体を濃縮し，その後顕微鏡で計数する方 法 ${ }^{12)}$ が良いと思われる。

本法の特徵の一つは, 遠心法とフィルター法を 組み合わせたことである。遠心法では通常リンパ 球は効率的に除去されるが，顆粒球は赤血球との 比重差が小さいため, 十分分離することが困難で ある。したがって，遠心操作の繰り返し法は， 2 回目以降の白血球の除去効率が悪く, しかも赤血 球の損失が大きくなる。一方，フィルター法は, 


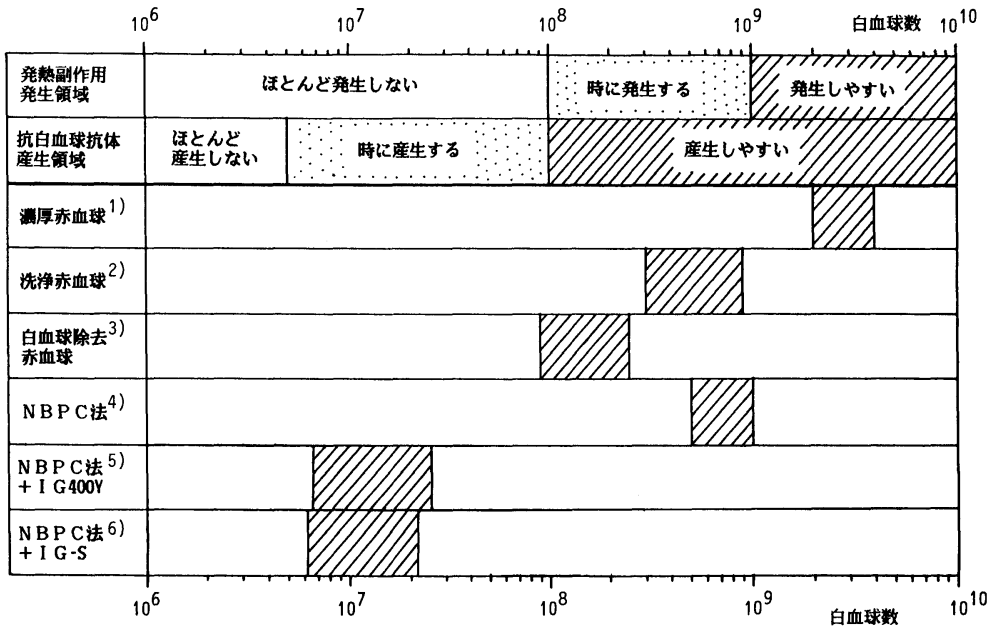

図 2 各種の赤血球製剤 $(400 \mathrm{~m} l$ 由来) の白血球残存量と輸血副作用発生度の関係 1）～3）日赤業務標準法，4） NBPC = non-button PC 法，5）Non-button PC 法で 製造したものを $400 \mathrm{~m} l$ 用イムガードフィルターで滤過，6）小型イムガードフィル ター（7g）を組み込んだ 5 連バッグシステム

白血球を選択的に除去する能力がある。ただし， 多量の白血球を含んだ血液を一度に通すと吸着力 や濾過速度が著しく低下する傾向がある。した がって，遠心法を先に実施することによってフィ ルターへの負担を軽減することができる，その結 果, 通常の $1 / 4 \sim 1 / 5$ 程度の小型フイルターで大き な効果が得られ，しかもフィルターをバッグシス テムに組み込むことも可能となる。また，フィル ター法では顆粒球が優先的に除去され易い傾向が あるので，リンパ球が優先的に除去される遠心法 との組み合わせは，白血球除去法として非常に合 理的な方法であると考学られる。

さらに，小型フィルターで白血球除去率を一層 向上させるため, 低温 $\left(4 \sim 6{ }^{\circ} \mathrm{C}\right)$ に打ける濾過 操作を試みたところ, 同じ綿重量のフィルターを 用いても白血球除去率が著しく上昇した。 反面, 低温操作では濾過時間が非常に長くなった。しか し, 当システムは closed system で操作できるの で，たとえば冷蔵室などでバッグを一晚吊るして おいて濾過するという方法も可能であり, 操作の 煩雑さを避けることができるであろら。また， closed system の利点から有効期限が長くなるの で，一定量をまとめて製造することもでき，むし
ろ作業効率が向上する可能性があると思われる.

現行の白血球除去製剂として使用されている洗 浄赤血球や白血球除去赤血球の問題点の一つは, open system で製造されていることである。その ため，有効期限が非常に短く(製造後24時間)，製 造の作業効率が悪いだけでなく，使用する際にも 不便である。それに対し，本法では closed system で製造できるので，短い有効期限による様々な制 約から解放されるであろら。

本法を実用化する上で今後検討を要すること は，製造工程が若干複雑になり，製造経費が高く なることである，操作性の改良のためには，分離 工程を自動化することが有効かも知れない.最近, このような自動分離装置の開発も試みられてい $3^{1117)}$. 経費に関しては, バッグ，フィルター, 保 存液などの追加によって確かに上昇するが，血浆 の採取量が増加すること, 赤血球の有効期限が延 びること, 輸血副作用が減少することなどを考慮 すれば，全体的経済効果はむしろ向上する可能性 があると思われる。また, 最近セパセルフィルター (旭メディカル) ${ }^{18)}$ やムガード $\mathrm{E}\left(\right.$ テルモ) ${ }^{199}$ な ぞ, 白血球除去効果の一層優れた新しいフィル ターも開発されてきているので，今回示した小型 
フィルターシステムとして応用すれば，さらに白 血球除去効果の高い方法を開発できる可能性もあ る.

以上のことから, 小型白血球除去フィルターを 組み込んだ 5 連バッグシステムは, non-button PC 法の利点に加えて, 白血球を約 $99 \%$ 除去した 濃厚赤血球（白血球残存量約 $1 \times 10^{7}$ 個）が得られ るので，輸血副作用の少ない血液製剤を製造する 方法として有用であると考兄られる，今後，この 方法の実用化についてさらに検討していきたい。

\section{まとめ}

現行の白血球除去赤血球よりさらに白血球除去 率の高い濃厚赤血球を closed system で製造でき るようにするため, 小型フィルターを組み込んだ 5 連バッグシステムを考案した。本法では，遠心 操作で約 $65 \%$ の白血球が除去され, 次に小型の Imugard Filter（カラム：2×10cm, 綿重量： $7 \mathrm{~g}$ ) による濾過操作で約 $98 \%$ の白血球が除去された。 さらに, 濾過操作を $4{ }^{\circ} \mathrm{C} て ゙$ 行うと, 白血球除去率 は $99 \%$ まで上昇した。この值を $400 \mathrm{~m} l$ 由来の濃厚 赤血球中の白血球残存量で示すと約 $1.4 \times 10^{7}$ 個と なり, 発熱等の副作用だけでなく HLA 抗体産生 の防止にも有効と思われる。本法は, 遠心法と濾 過法を組み合わせたことによりリンパ球と顆粒球 がともに効率的に除去でき，しかも closed system のため有効期限も長くなり, 白血球除去赤血 球の製造法として有用であると考兄られる。

\section{文献}

1) Dauset, J.: Leuko-agglutinins. IV. Leukoagglutinins and blood transfusion. Vox Sang., $4: 190-198,1954$.

2) Brittingham, T.E.: Immunologic studies on leukocytes. Vox Sang., 2: 242-248, 1957.

3) Brittingham, T.E. and Chaplin, H.J. Jr.: Febrile transfusion reactions caused by sensitivity to domor leukocytes and platelets. J.A.M.A., 165 : 819-825, 1957.

4) Goldstein, I.M., Free, H.J., Terasaki, P.I., et al. : Leukocyte transfusions-Role of leukocyte alloantibodies in determining transfusion response. Transfusion, $11: 19-24,1971$.

5) Fisher, M., Chapman, J.R., Ting, A., et al.: Alloimmunisation to HLA antigens following transfusion with leukocyte-poor and purified platelets suspensions. Vox Sang., 49 : 331-335, 1985.

6) Hathaway, W.E., et al.: Aplastic anemia, histiocytosis and erythrodermia in immunologically deficient children. N. Eng. J. Med., 273 : 953-958, 1965.

7）下山正徳：輸血による Graft-versus-host Disease (GVHD)，日輸血会誌，33:568-575, 1987.

8）榊原高之, 井野隆史：いわゆる術後紅皮症につい て. 日輸血会誌, $33: 576-580,1987$.

9) Uda, M., Ohkuma, S., Ishii, A., et al. : Preparation of blood components with saline-adenineglucose-phosphate-maltose quadruple-pack system. Transfusion, 25:325-329, 1985.

10）宇多正行, 岡田英俊, 石居昭夫, 他：Non-button PC 法：穏やかな条件を用いた血小板の製造法. 日輸血会誌, $31: 385-399,1985$.

11）宇多正行, 大熊重則：血液自動分離装置を用いた non-button PC 法. 第20回日赤薬剤会血液セン 夕一研究会, 1989年 4 月, 名古屋.

12) Vakkila, J. and Myllyla, G.: Amount and type of leukocytes in leukocyte-free red cell and platelet concentrates. Vox Sang., 53: 76 $-82,1987$.

13) Brittingham, T.E. and Chaplin, H.Jr.: The antigenicity of normal and leukemic human leukocytes. Blood, 17 : 139-165, 1961.

14) Perkins, H.A., Pane, R., Ferguson, J., et al.: Non hemolytic febrile transfusion reactions. Vox Sang., 11: 578-600, 1966.

15）村上省三, 佐藤公彦, 折居 喬：輸血による抗白 血球抗体の発生. Immunohaematology（免疫と血 液), $2: 1-7,1980$.

16) Sirchia, G., Parravicini, A., Rubulla, P., et al. : Effectiveness of red blood cells filtered through cotton wool to prevent antileukocyte antibody production in multitransfused patients. Vox Sang., 42: 190-197, 1982.

17）大谷 学, 鴐谷由紀子, 大山政則, 山本聖子, 白 木, 洋, 清川博之, 前田義章 : 自動分離器による 之白血球血液成分の調製。日輸血会誌，35：366 $-369,1989$.

18）長谷川秀弥，関口定美：可及的な白血球除去を試 みた赤血球製剂調製方法の検討．第36回日本輸血 学会総会講演抄録集 (新潟), p. 262, 1988.

19）武部道和, 津山典久, 坪倉只雄, 他：IG-E フィル ターを用いた no primingによる白血球除去の検 討. 第37回日本輸血学会総会講演要旨集 (神戸), p. 293, 1989. 